Review

\title{
Green Synthesis of Metallic Nanoparticles and Their Potential in Bio-Medical Applications
}

\author{
Tayyab Shafiq ${ }^{1}$, Mohammad Uzair ${ }^{2}$, Muhammad Junaid Iqbal ${ }^{1}$, Mohsin Zafar ${ }^{1}$, \\ Syed Jawad Hussain ${ }^{2}$, Syed Alasar Ali Shah ${ }^{1}$ \\ ${ }^{1}$ Department of Biosciences, COMSATS University, 44000, Islamabad, Pakistan. \\ ${ }^{2}$ Department of Biological Sciences, International Islamic University, 44000, Islamabad, Pakistan. \\ MCorresponding authors. E-mail: tayyabshafiqe@gmail.com
}

Received: Aug. 27, 2020; Accepted: Apr. 22, 202I; Published: May 27, 2021

Citation: Tayyab Shafiq, Mohammad Uzair, Muhammad Junaid Iqbal, Mohsin Zafar, Syed Jawad Hussain, and Syed Alasar Ali Shah,Green Synthesis of Metallic Nanoparticles and Their Potential in Bio-Medical Applications. Nano Biomed. Eng., 202 I, I3(2): I9I-206.

DOI: $10.5101 /$ nbe.v13i2.p191-206.

\begin{abstract}
Advances in multidisciplinary research have paved the way for the development of nanotechnological applications for utilization across a diversity of fields, including infectious diseases, agriculture, and the environment. Nanoparticles can be used for targeting and can play a vital role in the health sector. Using chemical methods, nanoparticles have been produced for a very long time, but due to the release of the harmful chemicals during their production and higher cost associated with the methodology, alternative methods such as green syntheses have been introduced. The green synthesis method is preferred over chemical methods attributed to the absence of fumes in green synthesis as compared to the chemical method. Nowadays, the antibiotic resistant microbes and the development of superbugs are a major problem in health sector, so as there are certain studies about the antimicrobial activities of metallic NPs, which can provide an alternative approach against these resistant microbes. The understanding about these NPs in bio-medical applications is not well studied. This systematic review will help the scientific community to understand the actual potential of these NPs as an effective antimicrobial and anticancer agent.
\end{abstract}

Keywords: Nanoparticles, Green synthesis, Metallic NPs, Anti-microbial, Anti-cancer, Characterization

\begin{abstract}
Abbreviations: $\mathrm{NPs}=$ Nanoparticles, $\mathrm{Au}$ NPs $=$ Gold nanoparticles, Ag NPs $=$ Silver nanoparticles, $\mathrm{Cu}$ NPs $=$ Copper nanoparticles, $\mathrm{TEM}=$ Transmission electron microscopy, $\mathrm{XRD}=\mathrm{X}$-ray diffraction, DLS $=$ Dynamic light scattering, FTIR $=$ Fourier transform infrared spectroscopy, MIC $=$ Minimum inhibitory concentrations
\end{abstract}

\section{Introduction}

In recent years, nanotechnology has emerged as a significant scientific field that deals with the development, manipulation, and utilization of nanometer-sized materials. Nanotechnology refers to the manipulation of nanomaterials, and the fabrication of devices that possesses at least one dimension within the size range below $100 \times 10^{-9} \mathrm{~m}$. Nanoparticles are diverse organic or inorganic particulates whose diameter is less than 100 nanometers. Nanoparticles are of great interest because of their astonishing chemical, physical, optical, and electrical properties. Nanoparticles may have an amorphous or crystalline shape with an exceptional atomic arrangement that can be functionalized and acts as a carrier of molecules, 
liquid droplets, or gases [1-3]. Due to their unique characteristics, nanoparticles attract a broad range of multidisciplinary fields. Nanoparticles have a great variety of applications in the biomedical field, such as disease diagnosis [4], targeted drug or gene delivery, biosensors and bio-imaging [5], antimicrobial properties [6], and other medicinal purposes.

Nanotechnology has notable applications in the biological domain that led to the fascinating convergent field of nanobiotechnology. Nanoparticles categorized into metallic, non-metallic, carbon-based, lipid-based, polymeric, or ceramic nanoparticles. This article focused mainly on noble Metallic nanoparticles of Gold (Au), Silver (Ag), and Copper $(\mathrm{Cu})$ due to their distinctive mechanical strength, optical and magnetic properties, low melting point, high aspect ratio, etc. They have potential applications in electronics, cosmetics, coatings, packaging, pharmaceuticals, and biomedical applications. Metallic nanoparticles synthesized by various physical, chemical, and biological methods [7]. However, the goal of this review is to systematically highlight green approach for the synthesis of metal nanoparticles that will benefit researchers working in the emerging field of Green nanobiotechnology, while providing a valuable guide for readers having a general interest in this hot topic.

\section{Green synthesis}

Synthesis of nanoparticles by different physiochemical techniques requires high energy-consumption, severe reaction conditions, expenses, and use of toxic chemicals. Synthetic methods of nanoparticle production also generate toxic bi-products that exert harmful effects on living beings and environment [8]. The biological synthesis, also known as green synthesis, is an alternative approach for nanoparticle generation. Green synthesis of nanoparticles is an emerging field in nanoscience, which involves the production of functional nanoparticles efficiently using plant extracts, bacteria, and fungi. The green synthesis not only a reliable, cost-effective, and less timeconsuming technique but also decrease toxic waste production [9].

Green approach for the synthesis of nanoparticles is the most preferred technique as it does not require high energy consumption, such as high temperature or pressure. In contrast, it emphasizes on utilizing mild reaction conditions and nontoxic precursors [10, 11]. Synthesizing metal nanoparticles by using plants and microbes grabs the attention of researchers widely. Recently, many metallic nanoparticles produced by the green approach and extensively used in applications of biomedical and pharmaceutical fields $[12,13]$. Here, we explore the biogenic synthesis of gold, silver, and copper nanoparticles and their possible application in the biological field.

Sources of biogenic synthesis of nanoparticles include plants, microbes like bacteria, yeast, fungi, etc. Besides other biotechnological importance, recent studies found that the microbes are possible bio factories for nanoparticles production [13]. Microorganisms, including bacteria, fungi, algae, and yeast, have significant capability to reduce and fabricate metal nanoparticles. Microbes can synthesize nanoparticles via two approaches: intracellular or extracellular methods [14]. The extracellular mechanism is the enzyme-mediated synthesis occurs outside of the cell. These enzymes may locate on the outer cell membrane of bacteria or secret out on media culture, reducing the metals into metal ions forming metal nanoparticles $[15,16]$. Although in the intracellular synthesis of nanoparticles, positive metal ions from the culture media diffuse into the cell via interacting with negative ions present on the cell wall. The reduction of metal ions occurs inside the cell by intracellular reducing enzymes, subsequently resulting in the accumulation of metal nanoparticles inside the cell [17].

Bacteria are of great interest in nanoparticle synthesis and other biotechnological applications because of high yield, easy to culture, and handle. Bacteria have a natural defense system, such as Crispr Cas, allows them to deal with stresses including $\mathrm{pH}$ change, toxic surrounding due to metallic ions concentration, etc. [18]. However, there are the certain limitations like slow synthesis rate, less control over size and shape of nanoparticles, and sterilize environment [19]. Therefore, a substitute choice for synthesizing nanoparticles is by using plants and their parts. Plants grab the attention of researchers worldwide due to their non-toxic nature, the natural ability to cap end, reducing metal ions, and the potential to accumulate heavy metals in their cells.

Plants-mediated nanoparticle synthesis is a straightforward and eco-friendly process that consumes no energy, inexpensive, and less time-consuming [20, 21]. Nanoparticles, generated by using plants or their parts are of the required size and shape non-toxic, 


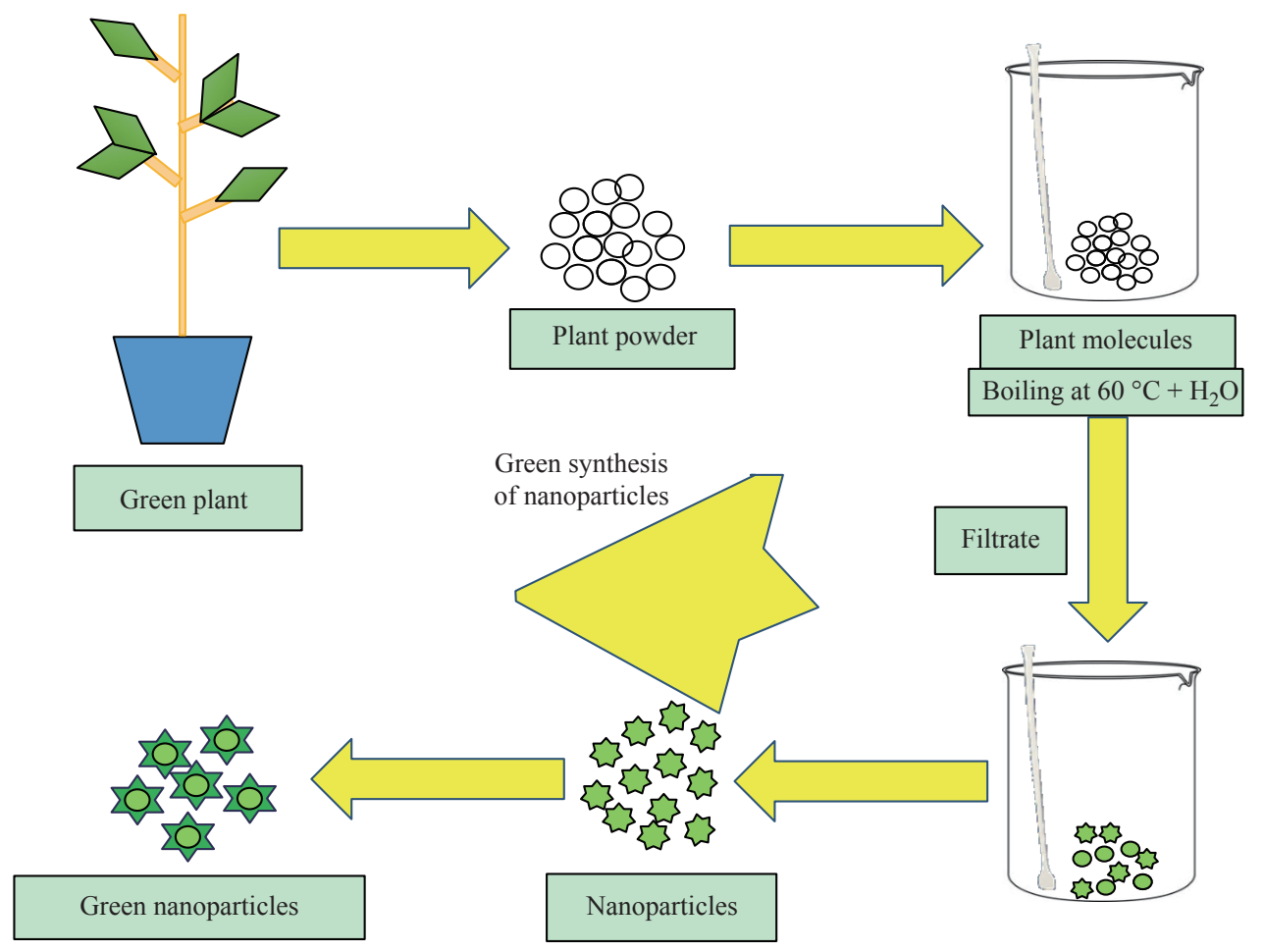

Fig. 1 Process of Green synthesis for nanoparticle generation.

stable having the enhance activity, biocompatibility, and influential penetration ability. Plant and its part contain various biochemical, including alkaloids, organic acids, polysaccharides, amino acids, vitamins terpenoids, flavonoids, and polyphenols that play a significant role in reducing, capping and stabilizing metal ions to nanoparticles $[11,22]$. Moreover, plantbased biosynthesis of nanoparticles has eased to scaling up the large-scale fabrication of nanoparticles. Owing to these features and advantages, the green approach of nanoparticles gains significant importance in every field directing on a greener environment. Extensive research work on the plant-mediated synthesis of the metal nanoparticle performed. Herein, we summarize some recent research on green synthesis of gold, silver, and copper nanoparticles.

\section{Green synthesis gold nanoparticles}

Gold nanoparticles (Au NPs) are a very remarkable and versatile class of nanoparticles that can be utilized in various aspects of biological and medicinal fields. They show effective outcomes in cancer therapy and drug delivery due to their biocompatibility, low toxicity, unique optical, and photo physical properties [23]. Site-specific drug delivery, photo thermal therapy, photodynamic therapy, and photo-imaging are various techniques for cancer detection and therapy, as these nanoparticles can absorb infrared radiation [24]. Au
NPs of required size and shape have been synthesized by different physical and chemical methods. Physical methods for gold nanoparticles synthesis include laser lithography, microwave, and ultraviolet (UV) radiation techniques. On the other hand, chemical synthesis based on reducing $\mathrm{Au}^{3+}$ in the presence of appropriate reducing agents and solvents [25-27]. Recent research work carried out on the synthesis of gold nanoparticles mainly focused on green synthesis. Biogenic synthesis of metallic nanoparticles gains significance importance due to its eco-friendliness and easiness. Green synthesis of gold nanoparticles by plants such as Musa acuminatacolla, Euphrasia officinalis, Stereospermum suaveolens, Clitoria Ternatea has been reported [2831]. The potential of bacteria, cyanobacteria, and fungi for nanoparticle synthesis also reported in various researches [32-37]. These approaches are not only of a green rapid synthesis kind but also considered as a better alternative to chemical synthesis. In the future, green synthesis of Au NPs with their different applications in drug delivery and antibacterial/ antifungal sensors can be enhanced. Table 1 is the list of gold nanoparticles fabrication by bacteria, fungi, algae, and plants explaining the different features of the production of gold nanoparticles.

\section{Green synthesis of silver nanoparticles}

Silver nanoparticles used extensively in biomedical 
Table 1 Green approach for the synthesis of gold nanoparticles using bacteria, fungi, and plants

\begin{tabular}{|c|c|c|c|c|c|c|}
\hline \multicolumn{7}{|c|}{ Green synthesis of gold nanoparticles } \\
\hline \multicolumn{7}{|c|}{ Source: Bacteria } \\
\hline Bacterial spp. & Strain & $\begin{array}{l}\text { Intracellular/ } \\
\text { Extracellular }\end{array}$ & $\begin{array}{l}\text { Size of NPs } \\
\quad(\mathrm{nm})\end{array}$ & Shape of NPs & Experiment design & Reference \\
\hline Bacillus marisflavi & YCIS MN 5 & Extracellular & $\sim 14$ & $\begin{array}{l}\text { Spherical, face- } \\
\text { centered cube }\end{array}$ & $\begin{array}{l}\text { Catalytic activity in the degradation of } \\
\text { Congo red and methylene blue }\end{array}$ & {$[32]$} \\
\hline Pseudo alteromonas & Bac178 & Extracellular & $12-90$ & Spherical & $\begin{array}{c}\text { Cytotoxicity and oxidative stress generation } \\
\text { in human normal fibroblast and melanoma } \\
\text { cells (A375) }\end{array}$ & {$[33]$} \\
\hline \multicolumn{7}{|c|}{ Source: Cyanobacteria } \\
\hline Leptolyngbya & JSC-1 & Extracellular & $100-200$ & Spherical & $\begin{array}{l}\text { Antimicrobial activity and membrane } \\
\text { disruption against } E \text {. coli and } S \text {. aureus }\end{array}$ & {$[34]$} \\
\hline \multicolumn{7}{|c|}{ Source: Fungi } \\
\hline $\begin{array}{l}\text { Trichoderma } \\
\text { hamatum }\end{array}$ & SU136 & Extracellular & $5-30$ & $\begin{array}{l}\text { Spherical, } \\
\text { Pentagonal, and } \\
\text { Hexagonal }\end{array}$ & $\begin{array}{c}\text { Antimicrobial activity against } \\
\text { Bacillus subtilis, Staphylococcus } \\
\text { aureusPseudomonas aeruginosa and } \\
\text { Serratia }\end{array}$ & {$[35]$} \\
\hline Jahnula. aquatica & $\mathrm{H} 58-5$ & Extracellular & 8,20 and 60 & Spherical & $\begin{array}{l}\text { Antibacterial and anticancer activity; effect } \\
\text { on HeLa cells nucleic acid }\end{array}$ & {$[36]$} \\
\hline \multicolumn{7}{|c|}{ Source: Algae } \\
\hline $\begin{array}{c}\text { Caulerpa racemosa } \\
\text { spp. }\end{array}$ & -- & Extracellular & $13.7-85.4$ & Spherical and oval & $\begin{array}{l}\text { Antibacterial activity and anti-cancerous } \\
\text { activity against the growth of human colon } \\
\text { adenocarcinoma (HT-29) cells }\end{array}$ & {$[37]$} \\
\hline \multicolumn{7}{|c|}{ Source: Plants } \\
\hline $\begin{array}{c}\text { Plant spp. } \\
\text { (Scientific name) }\end{array}$ & $\begin{array}{c}\text { Plant spp. } \\
\text { (Common name) }\end{array}$ & $\begin{array}{l}\text { Part used for } \\
\text { Extraction }\end{array}$ & $\begin{array}{l}\text { Size of NPs } \\
(\mathrm{nm})\end{array}$ & Shape of NPs & Experiment design & Reference \\
\hline $\begin{array}{l}\text { Musa } \\
\text { acuminatacolla }\end{array}$ & Wild Banana & Flower & $10.1-15.6$ & Spherical & $\begin{array}{l}\text { Pharmaceutical activity against extended } \\
\text { spectrum beta-lactamase (ESBL) gene } \\
\text { producing bacteria and anticancer efficacy. }\end{array}$ & [28] \\
\hline Euphrasia officinalis & Eyebright & Leaf & 40 & Quasi-spherical & $\begin{array}{c}\text { Anticancer activity against human lung } \\
\text { cancer (A549) and human cervical cancer } \\
\text { (HeLa) cell lines. Antibacterial activity and } \\
\text { biofilm inhibition activity }\end{array}$ & [29] \\
\hline $\begin{array}{l}\text { Stereospermum } \\
\text { suaveolens }\end{array}$ & Patala & Root bark & $\sim 27$ & Spherical & $\begin{array}{c}\text { Antimicrobial activity, antioxidant } \\
\text { properties, and ant proliferative effect on } \\
\text { human lung adenocarcinoma cells A549 } \\
\text { using MTT assay }\end{array}$ & {$[30]$} \\
\hline Clitoria Ternatea & $\begin{array}{l}\text { Asian } \\
\text { pigeonwings }\end{array}$ & Flower & 18.16 & Spherical & Biosynthesis and characterization & {$[31]$} \\
\hline
\end{tabular}

as nano medicine due to their unique therapeutic, antimicrobial, Anticancer, and antioxidant features. Silver-based nanoparticles utilized widely in wound healing ointments, antifungal medicines, anticancer therapy, water disinfection, and other medicines to treat infections $[38,39]$. Generally, silver nanoparticles can be synthesized by different physio-chemical approaches. The physical synthesis of Ag NPs includes evaporation-condensation technique, laser ablation, thermal decomposition, sonication, mechanical grinding, irradiation, etc. [40, 41]. However, chemical methods for Ag NPs involve chemical reduction, electrochemical, inert condensation method, sol-gel method, and pyrolysis. In the era of green synthesis, silver nanoparticles also synthesized by biological systems including plants, bacteria, and fungi. Bacterial species (such as E. coli, B. brevis), cyanobacteria (C. vulgaris), and fungi (T. atroviride, M. phaseolina) reported in recent years $[42,46]$. An extensive volume of literature reported successful nanoparticle synthesis using various plants, such as $V$. amygdalina, $N$. sativa, $W$ coagulans, C. illinoinensis [39, 47-49]. Among the different NPs, Ag NPa have picked up a lot of consideration because of their remarkable antimicrobial properties. However, there are some concerns about the synthesis of these nanoparticles, for example, utilization of toxic solvents and chemicals, and their harmful sideeffects have prompted the green synthesis of Ag NPs. This eco-friendly strategy joins utilization of natural agents, microbes or plants as capping and reducing agent. Some of the recent reports of biogenic synthesis of silver nanoparticles are presented in Table 2.

\section{Synthesis of copper nanoparticles}

Owing to its antibacterial and conducting characteristics, copper is one of the well-known 
Table 2 Green approach for the synthesis of silver nanoparticles using bacteria, fungi, and plants

\begin{tabular}{|c|c|c|c|c|c|c|}
\hline \multicolumn{7}{|c|}{ Green synthesis of silver nanoparticles } \\
\hline \multicolumn{7}{|c|}{ Source: Bacteria } \\
\hline Bacterial spp. & Strain & $\begin{array}{l}\text { Intracellular/ } \\
\text { Extracellular }\end{array}$ & Size of NPs (nm) & Shape of NPs & Experiment design & Reference \\
\hline Bacillus brevis & NCIM 2533 & Extracellular' & $41-68$ & Spherical & Antibacterial activity against pathogens & {$[44]$} \\
\hline Escherichia coli & Top 10 (Ec-Ts) & Extracellular & 10.6 & Spherical & Antimicrobial activity & {$[42]$} \\
\hline \multicolumn{7}{|c|}{ Source: Cyanobacterium } \\
\hline Chlorella vulgaris spp. & -- & Extracellular & 10 & Spherical & $\begin{array}{l}\text { Antimicrobial activity, anti-biofilm, } \\
\text { and in vitro cytoxicity }\end{array}$ & {$[43]$} \\
\hline \multicolumn{7}{|c|}{ Source: Fungi } \\
\hline Trichoderma atroviride & SCFUN1511 & Extracellular & $10-15$ & Spherical & Antifungal and Antibacterial activity & {$[45]$} \\
\hline $\begin{array}{c}\text { Macrophomina phaseolina } \\
\text { spp. }\end{array}$ & -- & Extracellular & $5-30$ & Spherical & $\begin{array}{c}\text { Antibacterial activity and effects on } \\
\text { seed germination and protection of } \\
\text { soybean. }\end{array}$ & {$[46]$} \\
\hline \multicolumn{7}{|c|}{ Source: Plants } \\
\hline $\begin{array}{c}\text { Plant spp. } \\
\text { (Scientific name) }\end{array}$ & $\begin{array}{c}\text { Plant spp. } \\
\text { (Common name) }\end{array}$ & $\begin{array}{l}\text { Part used for } \\
\text { Extraction }\end{array}$ & Size of NPs (nm) & Shape of NPs & Experiment design & Reference \\
\hline Vernonia amygdalina & Bitter leaf & Leaf & $2-10$ & Spherical & $\begin{array}{c}\text { Antibacterial activity against Coliform } \\
\text { and Staphylococcus aureus bacterial } \\
\text { strains }\end{array}$ & {$[47]$} \\
\hline Nigella sativa & Fennel flower & Seed & $8-80$ & Spherical & $\begin{array}{l}\text { Antibacterial, Ant biofilm, and } \\
\text { Anticancer Activity }\end{array}$ & {$[48]$} \\
\hline Withania coagulans & Vegetable Rennet & Fruit & $10-40$ & Spherical & $\begin{array}{l}\text { Antibacterial activity. Conjugated with } \\
\text { Levofloxacin, tested against bacteria }\end{array}$ & [39] \\
\hline Carya illinoinensis & Pecan & Leaf & $12-30$ & $\begin{array}{l}\text { Face-centered } \\
\text { cubic }\end{array}$ & $\begin{array}{l}\text { Antibacterial activity against Gram- } \\
\text { positive and Gram-negative bacteria }\end{array}$ & [49] \\
\hline
\end{tabular}

Table 3 Green approach for the synthesis of copper nanoparticles using bacteria, fungi, and plants

\begin{tabular}{|c|c|c|c|c|c|c|}
\hline \multicolumn{7}{|c|}{ Green synthesis of copper nanoparticles } \\
\hline \multicolumn{7}{|c|}{ Source: Bacteria } \\
\hline Bacterial spp. & Strain & $\begin{array}{l}\text { Intracellular/ } \\
\text { Extracellular }\end{array}$ & $\begin{array}{l}\text { Size of NPs } \\
(\mathrm{nm})\end{array}$ & Shape of NPs & Experiment design & Reference \\
\hline $\begin{array}{l}\text { Pseudomonas } \\
\text { fluorescens }\end{array}$ & ATCC 17397 & Extracellular & $10.2-35.2$ & Spherical & $\begin{array}{l}\text { Antifungal activity against some } \\
\text { Aspergillus fungal species }\end{array}$ & {$[56]$} \\
\hline $\begin{array}{l}\text { Pseudomonas } \\
\text { silesiensis }\end{array}$ & A3 & Extracellular & 66.12 & Spherical & $\begin{array}{l}\text { Biosynthesis using bacterial supernatant optimized } \\
\text { with certain agro-industrial byproducts }\end{array}$ & [57] \\
\hline Klebsiella pneumonia & SN35 & Extracellular & $19.01-47.47$ & Spherical & $\begin{array}{c}\text { Effect of Cu NPs on } \mathrm{Cr} \text { concentration on wheat } \\
\text { plants and soil Cr level }\end{array}$ & [59] \\
\hline Escherichia sp. & SINT7 & Extracellular & $22.33-39$ & Spherical & $\begin{array}{l}\text { Photo catalyst activity for azo dye degradation } \\
\text { and treatment of textile effluents }\end{array}$ & [58] \\
\hline \multicolumn{7}{|c|}{ Source: Fungi } \\
\hline $\begin{array}{l}\text { Botryosphaeria } \\
\text { rhodina } \text { spp }\end{array}$ & -- & Extracellular & $2-50$ & Spherical & Cytotoxic activity against lung (A549) cancer cell & {$[60]$} \\
\hline \multicolumn{7}{|c|}{ Source: Plants } \\
\hline $\begin{array}{c}\text { Plant spp. } \\
\text { (Scientific name) }\end{array}$ & $\begin{array}{c}\text { Plant spp. } \\
\text { (Common name) }\end{array}$ & $\begin{array}{l}\text { Part used for } \\
\text { Extraction }\end{array}$ & $\begin{array}{l}\text { Size of NPs } \\
\quad(\mathrm{nm})\end{array}$ & Shape of NPs & Experiment design & Reference \\
\hline Persea americana & Avocado & Seeds & 35.6 & Spherical & Antibacterial activity & [53] \\
\hline Citrus reticulata & Tangerine & Peels & $54-72$ & Round & $\begin{array}{l}\text { Mitigation of microbial bio deterioration } \\
\text { and acid corrosion of pipework steel. }\end{array}$ & [54] \\
\hline Moringa oleifera & Drumstick tree & Leaves & $35.8-49.2$ & Amorphous & Antifungal, antimicrobial, and antioxidant activity & [55] \\
\hline Allium eriophyllum & Boiss & Leaves & $25-35$ & Spherical & $\begin{array}{l}\text { Antimicrobial activity and cutaneous } \\
\text { wound-healing potentials }\end{array}$ & [51] \\
\hline
\end{tabular}

elements. Copper nanoparticles (Cu NPs), due to highly specific surface area and quantum effects, possess significant UV sensitivity, conductance, electrical, and catalytic properties [50]. Cu NPs exert a strong antimicrobial activity, hence significantly use in water sterilization, wound healing, and dressing. $\mathrm{Cu}$ NPs show effective action against dangerous pathogens and infectious diseases such as cholera [51, 
52]. Various physical and chemicals methods applied to synthesize $\mathrm{Cu}$ NPs. Physical methods include laser ablation, microemulsion, radiolysis, microwave irradiation, and aerosol techniques. On the other hand, micelles formation or reducing copper ions methods are chemical methods for $\mathrm{Cu}$ NPs synthesis [52]. Green synthesis of copper nanoparticles by plants reported, including $P$. americana, $C$ reticulate, M. oleifera, and A. eriophyllum [51, 53-55]. Several microbes' P. fluorescens, $P$. silesiensis, K. pneumonia, Escherichia, and B. rhodina utilized for green synthesis of the copper nanoparticles [56-60]. These particles have very small size and high surface area that's why $\mathrm{Cu}$ NPs have high potential to be used in targeted cancer therapy. Some of the recent reports of biogenic synthesis of copper nanoparticles are presented in Table 3.

\section{Characterization of nanoparticles}

Various techniques are used for the characterization of nanoparticles. Here we will discuss basics of few techniques, which are being used for characterization of copper nanoparticles, these include absorption spectrophotometry (UV-Vis) and Fourier Transforms Infrared Spectroscopy (FTIR), XRD and Scanning Electron Microscopy (SEM) [61].

\section{UV-Vis spectrophotometry}

Many molecules absorb visible or ultraviolet light. This spectrophotometer analysis records the optical density (O.D) and intensity of Absorption (A) when the light of a certain frequency is passed through the sample. Using a UV-Vis spectrophotometer, the synthesis of Metallic nanoparticles is confirmed by observing the absorption peak at regular time intervals in the range of $200-400 \mathrm{~nm}$ [62].

\section{FTIR}

FTIR (Fourier Transform Infra-Red Spectroscopy) is a most useful technique to identify the organic chemicals and it also characterizes some inorganics, including paints, polymers, and drugs. This technique will identify which reducing agent is present in the characterized extract to perform capping and reducing activity. This technique used to identify the bindings sites present in the molecules under a certain range of frequency using infra-red light. It is the most powerful tool used for the isolation and identification of organic molecular groups, functional groups, and side chains, all of these are having characteristic vibration frequencies in infrared range [63].

\section{Transmission electron microscopy}

Transmission Electron Microscopy (TEM) is used for the evaluation of size, shape, and overall morphology of obtained nanoparticles. It will identify the dispersion and regularity of a given nanoparticles. The regularity can be seen as well by this technique [64].

\section{Characterization Results of $\mathbf{A g}$ NPs}

To know the exact size, shape the molecular integrity of a synthesized nanoparticle, we have to perform these characterization results. This review will give a detailed study of the characterization results of silver Np's cited in various research.

\section{UV-Vis spectrophotometry}

Various studies indicate the absorption peaks of Ag NPs are mainly from $300-500 \mathrm{~nm}$, this variance in the absorption peaks, mainly depends on the source extract. In the case of Andean blackberry fruit extract, the absorption peak is around a new peak appears around $380-480 \mathrm{~nm}$ and a maximum peak at $435 \mathrm{~nm}$ these generated particles are spherical and aggregated [65]. Synthesis of Ag NPs with the fruit extract of $C$. viscosa gives the dark brown color in the solution, which gives the Plasmon resonance property of silver. The UV visible spectrophotometer has the maximum absorbance at $410-430 \mathrm{~nm}$. The formation of Ag NPs monitored with respect to different time intervals under UV visible spectroscopy. After some time, the production of Ag NPs increases [66]. In the case of coffee extract, the spectra show the maximum absorbance peak within the range of 447-459 $\mathrm{nm}$ [67]. Using Psidium guajava leaf extract, the Ag NPs have changed in color from yellow to dark brown, which depends on the size of nanoparticles. This change in the color arises due to the excitation of Surface Plasmon Resonance (SPR). The maximum absorbance peak is observed at $428-435 \mathrm{~nm}$ [68].

\section{FTIR study}

FTIR spectroscopy is used to identify the molecular interaction and functional groups present in the extract solution and of Ag NPs. In case of possible biomolecule present in Andean blackberry fruit extract, which is responsible for the production of Ag NPs. The various functional groups and interaction of various biomolecule can be observed at 3270, 2933, and 1642 
$\mathrm{cm}$ could be due to the $\mathrm{OAH}$, aliphatic $\mathrm{CAH}$, and $\mathrm{C}$, $\mathrm{O}$ stretching vibration of flavonoids/phenolic groups. The peak which is present at $1408 \mathrm{~cm}$ corresponds to the OAH bend of effects of the Ag NPs most possible is the result of the interaction of $\mathrm{Ag}$ atoms with the functional groups of the ABFE [65]. By using Cleome viscosa, the absorption peaks present at 539, 781, 1060, 1606,2920 , and $3420 \mathrm{~cm}^{-1}$, which indicates that the plant molecules are acting as capping agents that are bound on Ag NPs [66]. In another study, the FTIR spectrum obtained of Ag NPs synthesized by Coffea arabica seed extract is between $4000-400 \mathrm{~cm}^{-1}$, respectively [67]. FTIR analysis of Psidium guajava leaf extract showed bands at $3430 \mathrm{~cm}^{-1}(-\mathrm{OH})$ and shoulder at $1730 \mathrm{~cm}^{-1}$ due to $(\mathrm{C}=\mathrm{O})$ and $1620 \mathrm{~cm}^{-1}$ (amide), $1450 \mathrm{~cm}^{-1} \quad(\mathrm{C}-\mathrm{C}=\mathrm{C}), 1363 \mathrm{~cm}^{-1} \quad$ (N-O), 1040 $\mathrm{cm}^{-1}$ (C-O), $835 \mathrm{~cm}^{-1}$ (alkenes), and $702 \mathrm{~cm}^{-1}$ (aromatic rings) [68].

\section{Transmission electron microscopy analysis}

Various studies provide a detailed analysis of the size morphology and various other factors of synthesized nanoparticles by visualizing them through the transmission electron microscope. The morphology and size of the synthesized nanoparticles identified by TEM. The average size obtained by the previous research was around $12-50 \mathrm{~nm}$, and few particles are spherical, and some are also present in an aggregated form [65]. In another study, the average size obtained was around $34 \mathrm{~nm}$, and it also reveals the morphology in which most of the particles were well dispersed and spherical [10]. Another case for the green synthesis of Ag NPs done from Coffee extract have a spherical and ellipsoidal morphology under TEM analysis. The obtained diameter is in the range of 10-40 nm [67]. Obtained Ag NPs from Psidium guajava leaf extract exhibit the average size under TEM analysis from 14$35 \mathrm{~nm}[68]$.

\section{Characterization Results of $\mathrm{Au}$ NPs}

This section will explain the detailed characterization result of Au NPs for the size, shape, and morphological analysis of the solid nanoparticle produced through bioinspired synthesis.

\section{UV-Vis spectrophotometry}

$\mathrm{Au}$ NPs produced by extracellular extraction from marine bacteria Enterococcus $s p$, which is obtained by the gold ion reaction mixture done at different times. The average absorbance peak is obtained at $545 \mathrm{~nm}$ [69]. In the case of the green synthesis of $\mathrm{Au}$ NPs by Citrus maxima extract, the change of color and due to the SPR property will indicate the presence of NP's and the UV-vis spectra after 30 minutes of exposure will give the maximum absorbance peak at 510-540 nm [70]. In other research, the preparation of $\mathrm{Au}$ NPs from the aqueous extract of T. conoides and S. tenerrimum. After analyzing the UV-VIS spectra of $T$. conoides, the average absorption is around 536 $\mathrm{nm}$, and after some time, approximately 90 minutes, the absorption was observed at around $540 \mathrm{~nm}$. In the case of $S$. tenerrimum, the absorption peak is obtained at a little less reading, which is around $520-560 \mathrm{~nm}$ [71]. In research in which Au NPs is synthesized from brown algae, Cystoseirabaccata the characteristic (SPR) absorption band of gold nanoparticles at $532 \mathrm{~nm}$ confirms the formation of nanoparticles [72].

\section{FTIR}

As mentioned earlier, the FTIR study is to analyze the molecular structure and bonding among various functional groups. So, in the study where Au NPs are synthesized from Enterococcus sp. the FTIR spectra shows the peaks at 3621 and $3429 \mathrm{~cm}^{-1}$, which related to $\mathrm{OAH}$ stretching groups of alcohol, phenol, and another band at 3549 show the stretching of Carboxylic groups [69]. The FTIR spectrum of Cystoseira baccata shows a peak at $3402 \mathrm{~cm}^{-1}$, which relates to $\mathrm{NH}$ vibration. The $\mathrm{CH}$ stretch is at $2937 \mathrm{~cm}^{-1}$, and the bank at 1078 could be due to $\mathrm{C}-\mathrm{OH}$ vibrations [72]. Synthesis of Au NPs from the extracts of T. conoides and $S$. tenerrimum were analyzed by the FTIR spectra the spectrum of both extracts and Au NPs is under the range of 400-4000 $\mathrm{cm}^{-1}$ and with a resolution of $4 \mathrm{~cm}^{-1}$ [71]. In recent research, the FTIR spectra of C.maxima fruit extract and Au NPs is at 617, 1125, 1376, 1658, and $3278 \mathrm{~cm}^{-1}$. The peak present at 3278 shows the $\mathrm{O}-\mathrm{H}$ stretching which can be ascorbic acid extract and flavonoids [73].

\section{Transmission electron microscopy analysis}

To visualize the morphology of nanoparticles synthesized by various biological agents, TEM analysis of the respective NP's is done to check out the exact size and shape. In the research where Au NPs were synthesized by Cystoseira baccata, the TEM results shown that the generated NP's are round and spherical for both of free and embedded nanoparticles, and the average size ranges to $8.4 \pm 2 \mathrm{~nm}$ [72]. Au NPs synthesized from E.coli sp. under the TEM analysis 
shows that most of the particles were aggregated, only a few are scattered, the shape was mostly spherical, and the average size is around $10 \mathrm{~nm}$ [69]. The production of Au NPs from filamentous fungi, the TEM analysis showed that the Bio Au NPs produced by the PDB control were varied in size ranging from 1 to $80 \mathrm{~nm}$ and had mostly spherical and hexagonal shape [74]. TEM images of Au NPs produced from Citrus maxima extract show that the morphology of most of the particles was a rod and spherical like and the average size of particles was around $25.7 \pm 10 \mathrm{~nm}$ [73].

\section{Characterization Results of $\mathrm{Cu}$ NPs}

Synthesis of plant-mediated copper nanoparticles $(\mathrm{Cu}$ NPs) confirmed by obtaining various characterization results. In this study, various approaches performed (Table 4).

\section{UV-Vis spectrophotometry}

In the research where $\mathrm{Cu}$ NPs produce from the aqueous extract of $A$. plexiform, the visual color change observed under UV-visible spectroscopy. The color changes from blue to dark blue after $24 \mathrm{hrs}$. In the end, a darkish color obtained due to SPR property, the average absorbance peak of all the solutions including leaf extract, copper sulfate solution, and
$\mathrm{Cu}$ NPs at 203-230 nm [75]. The synthesis of Cu NPs from Syzygium aromaticum bud extract observed under UV-Vis spectroscopy. The reduction of copper acetate into copper observed by this spectrum, the change in the color observed, and also the absorbance peak lies at 550-650 nm [76]. Cu NP synthesis from Eclipta prostrata leaves extracts under the optimum conditions that were $50^{\circ} \mathrm{C}, 3 \mathrm{mM} \mathrm{Cu}(\mathrm{OAc}) 2, \mathrm{pH} 6$, and a $30 \mathrm{~min}$ incubation period. The UV-Vis spectrum showed the average absorbance peak $565 \mathrm{~nm}$ and SPR bands observed within 1 hour [77]. From the leaf extract of Azadirachta indica leaves, the extract and $\mathrm{CuCl}_{2}$ solution were added, the solution color changes from light blue to green, and after some time it turns into dark brown. The color change is due to the SPR. The average absorbance peak observed from $550-600 \mathrm{~nm}$ [78].

\section{FTIR}

The FTIR study of A. laxiflora leaf extract to check out the biomolecules act for the reduction of $\mathrm{CuSO}_{4}$ to $\mathrm{Cu}$ NPs and also acting as the stabilizing and acting agent. The peaks observed at $3472 \mathrm{~cm}^{-1}$, which indicates the vibration at the $\mathrm{O}-\mathrm{H}$ phenolic compound, and the peak at 2358 shows the presence of $\mathrm{C}-\mathrm{N}$ or C-C vibrations [75]. FTIR analysis carried out for the Syzygium aromaticum bud extract for the biosynthesis of $\mathrm{Cu}$ NPs. The bands or peaks observed at the 3301

Table 4 Characterization results

\begin{tabular}{|c|c|c|c|c|}
\hline Different Plant Extract & UV-Vis (nm) & FTIR $\left(\mathrm{cm}^{-1}\right)$ & TEM (nm) & Reference \\
\hline \multicolumn{5}{|c|}{ Ag NPs } \\
\hline Andean blackberry & $380-480$ & 3270,2933 and 1642 & $12-50$ & [65] \\
\hline Cleome viscosa & $410-430$ & $539,781,1060,1606,2920$ and 3420 & 34 & [66] \\
\hline Coffea arabica & $447-459$ & $4000-400$ & $10-40$ & [67] \\
\hline Psidium guajava & $428-435$ & $1730,1620,1450,13631040,835,702$ & $14-35$ & [68] \\
\hline \multicolumn{5}{|c|}{ Au NPs } \\
\hline Enterococcus sp & 545 & 3621,3429 and 3549 & 10 & [69] \\
\hline Citrus maxima & $510-540$ & $617,1125,1376,1658$ and 3278 & $25.7 \pm 10$ & [73] \\
\hline $\begin{array}{c}\text { T. conoides } \\
\text { S. tenerrimum. }\end{array}$ & $536-520$ & $4000-400$ & $10-40$ & [71] \\
\hline Cystoseira baccata & 532 & 3402,2937 and 1078 & $8.4 \pm 2$ & [72] \\
\hline \multicolumn{5}{|c|}{$\mathrm{Cu}$ NPs } \\
\hline A. laxiflora & $203-230$ & 3472 and 2358 & $3.29 \pm 0.57$ & [75] \\
\hline Syzygium aromaticum & $550-650$ & 3301 and 2981 & 15 & [76] \\
\hline Eclipta prostrata. & 565 & $3333,2971,1615$ and 1038 & $28-45$ & [77] \\
\hline Azadirachta indica & $550-600$ & 2922, 2371, 1631 and 1546 & 48 & [78] \\
\hline
\end{tabular}


$\mathrm{cm}^{-1}$ indicate the presence of alcohol and hydroxyl groups. The stretching of $\mathrm{C}-\mathrm{H}$ and $\mathrm{C}-\mathrm{N}$ groups are located at $2981 \mathrm{~cm}^{-1}$ [76]. Green synthesis of Cu NPs from E.prostrata leaf extract shows various bands in FTIR analysis after looking at it carefully. It observed that bands that appeared at $3333 \mathrm{~cm}^{-1}$ indicate the presence of the hydroxyl group, band at $2917 \mathrm{~cm}^{-1}$ shows the presence of methylene group, and there are two more bands at 1615 and 1038 for aliphatic fluoro compounds [77]. FTIR spectra of Azadirachta indica leaves and $\mathrm{Cu}$ NPs the major bands or peaks observed at $2922 \mathrm{~cm}^{-1}$ show O-H stretching, another band at $2371 \mathrm{~cm}^{-1}$ shows the stretching of aromatic amine, $1631 \mathrm{~cm}^{-1}$ indicates $\mathrm{C}=\mathrm{O}$ stretching, and a band at $1546 \mathrm{~cm}^{-1}$ shows $\mathrm{C}=\mathrm{C}$ stretching [78].

\section{Transmission electron microscopy analysis}

TEM analysis of $\mathrm{Cu}$ NPs synthesized from $A$. laxiflora leaf extract indicates that mostly the particle produced are spherical, well dispersed, the particle size ranges from 2.83 to $3.97 \mathrm{~nm}$, and the average size is around $3.29 \pm 0.57 \mathrm{~nm}$. The plant extract has the biomolecules which are essential for the bio reduction of Copper salt into $\mathrm{Cu}$ NPs [75]. Biosynthesized $\mathrm{Cu}$ NPs from Syzygium aromaticum bud extract shows that the particles are mostly monodispersed, and also spherical. There is no agglomeration in the particles, and the average size is around $15 \mathrm{~nm}$ [76]. The aqueous extract of Ecliptaprostrata leaves extract and salt solution of $\mathrm{Cu}(\mathrm{OAc})_{2}$ have some monodispersed particles, some are also spherical, and the average size of $\mathrm{Cu}$ NPs is around 28 to $45 \mathrm{~nm}$ [77]. Cu NPs synthesized from Azadirachta indica leaves extract are cubical, which is observed under TEM analysis. These results also show that NPs are covered by a thin layer of organic material, which acts as a capping agent. The average size observed around $48 \mathrm{~nm}$ [78].

\section{Analysis of biological applications of metallic nanoparticles}

Advancements in nanobiotechnology have an exceptional impact on agriculture, food, and biomedical sciences. Nanomaterials and nanoparticles emerge as nanomedicines and contribute extensively to pharmaceutical sciences and health care. Among the other nanoparticles, metallic nanoparticles got prestigious places due to their distinctive chemical, optical, electrical, and particularly biological characteristics [55]. Metallic nanoparticles show effective outcomes in antimicrobial, antioxidant, and Anticancer activities. Metallic nanoparticles also found very practical in drug delivery, biosensors, bioimaging, and other diagnostic applications. In this review, an attempt made to project the antibacterial and Anticancer activity of green synthesized gold, silver, and nanoparticles. The biological techniques, for example green synthesis of metallic nanoparticles from plants is superior to chemicals synthesis. Some advantages of green synthesis of metallic nanoparticles over chemical and physical synthesis are less toxic, eco-friendliness, low energy usage, and cost effective.

\section{Antimicrobial activity of metallic nanoparticles}

Microbial infectious diseases are a serious matter of health care all over the world. The most threatening problem is the upsurge of antimicrobial resistance of bacteria, creating a global health crisis. Antibiotic resistance may happen naturally however, misuse of antibiotics also increases the process. Due to antimicrobial-resistance in bacterial species, the number and severity of infections have increased, increasing the mortality rate globally. According to the World Health Organization, 700000 deaths occur annually due to drug-resistance bacteria, consisting of 23000 deaths from rifampicin-resistant and multidrug-resistant tuberculosis [79]. Hence, new strategies and more research required to tackle problems regarding antimicrobial resistance all over the world [80]. Metal nanoparticles emerged as effective antimicrobial agents, offers a promising approach for combating drug-resistant pathogens $[1,81]$. The specific mechanism of nanoparticles inducing antimicrobial activity is still unclear, although proposed possibilities exist which may damage DNA, disrupts cell wall, protein dysfunction, or producing reactive oxygen species (ROS) [82]. The metallic nanoparticles have been emerging as an efficient alternative method to antibiotics and appear to have strong antibacterial activity against multi-drug resistant bacteria and pathogenic bacteria. Green synthesized metallic nanoparticles show potent antimicrobial activity against several species of bacteria. We have summarized the studies on the antibacterial efficacy of plant-mediated synthesis of gold, silver, and copper nanoparticles (Table 5).

\section{Antimicrobial activity of gold nanoparticles}

Many pieces of research done on green synthesized and eco-friendly gold nanoparticles to explore their 
Table 5 Summary of antimicrobial activity of green synthesis of metallic nanoparticles and their mechanism

\begin{tabular}{|c|c|c|c|c|c|c|c|}
\hline \multicolumn{8}{|c|}{ Antimicrobial activity of biosynthesized metallic nanoparticles } \\
\hline $\begin{array}{l}\text { Metallic } \\
\text { NPs }\end{array}$ & Source & $\begin{array}{c}\text { Size of } \\
\text { NPs (nm) }\end{array}$ & $\begin{array}{l}\text { Bacterial } \\
\text { spp. used }\end{array}$ & $\begin{array}{l}\text { Diameter of zone } \\
\text { of inhibition } \\
(\mathrm{mm})\end{array}$ & $\begin{array}{c}\mathrm{Cu} \text { NPs } \\
\text { concentration } \\
(\mu \mathrm{L})\end{array}$ & $\begin{array}{l}\text { Antibacterial } \\
\text { mechanism }\end{array}$ & Reference \\
\hline $\mathrm{Au}$ NPs & Leptolyngbya JSC-1 & $100-200$ & $\begin{array}{l}\text { S. aureus } \\
\text { E. coli }\end{array}$ & $\begin{array}{l}14 \pm 2 \\
18 \pm 2\end{array}$ & $80 \mu \mathrm{L}$ & $\begin{array}{l}\text { Au NPs penetrate into bacterial } \\
\text { cell, produce ROS, which } \\
\text { induces oxidative stress } \\
\text { causing bacterial cell }\end{array}$ & [34] \\
\hline $\mathrm{Au}$ NPs & Black lemon & 15 & $\begin{array}{c}\text { Pseudomonas } \\
\text { aeruginosa } \\
\text { Staphylococcus aureus }\end{array}$ & $\begin{array}{l}12 \\
16 \\
18 \\
11 \\
13 \\
14\end{array}$ & $\begin{array}{l}25 \mu \mathrm{L} \\
50 \mu \mathrm{L} \\
100 \mu \mathrm{L}\end{array}$ & $\begin{array}{l}\text { ROS generated and damage } \\
\text { bacterial cell by oxidative } \\
\text { stress mechanism }\end{array}$ & [83] \\
\hline $\mathrm{Au}$ NPs & Catharanthusroseus & $10-100$ & $\begin{array}{c}\text { Micrococcus luteus } \\
\text { Salmonella } \\
\text { typhimurium } \\
\text { Enterococcus fecalis } \\
\text { Aeromonas liquefaciens }\end{array}$ & $\begin{array}{l}12-17 \\
13-14 \\
14-16 \\
17-19\end{array}$ & $\begin{array}{l}15 \mu \mathrm{L} \\
30 \mu \mathrm{L}\end{array}$ & $\begin{array}{l}\text { Au NPs interact and penetrate cell } \\
\text { membrane. Inhibits DNA replication } \\
\text { by targeting phosphorus/sulphur, } \\
\text { eventually, cause cell death }\end{array}$ & [84] \\
\hline Ag NPs & Ajuga parviflora & $1-16$ & $\begin{array}{c}\text { Pseudomonas } \\
\text { aeruginosa } \\
\text { Escherichia coli } \\
\text { Staphylococcus aureus } \\
\text { Bacillus subtilis }\end{array}$ & $\begin{array}{l}12.89 \pm 0.44 \\
14.33 \pm 0.78 \\
12.91 \pm 0.64 \\
13.96 \pm 0.62 \\
13.21 \pm 0.64 \\
14.58 \pm 0.41 \\
12.82 \pm 0.42 \\
14.02 \pm 0.72\end{array}$ & $\begin{array}{r}75 \mu \mathrm{L} \\
100 \mu \mathrm{L}\end{array}$ & $\begin{array}{l}\text { Ag NPs penetrate into bacterial cell, } \\
\text { generate free radicals, which which } \\
\text { disrupts the metabolic activities } \\
\text { causing DNA damage, resulting in } \\
\text { the cell death. }\end{array}$ & [85] \\
\hline Ag NPs & Hydnocarpus alcalae & $22-48$ & $\begin{array}{c}\text { Escherichia coli } \\
\text { Staphylococcus aureus }\end{array}$ & $\begin{array}{l}10 \\
10\end{array}$ & $1 \mu \mathrm{g} / \mathrm{mL}$ & $\begin{array}{l}\text { Altering the physical and chemical } \\
\text { composition of bacteria cell, reacts } \\
\text { with phosphorus/sulphur, damaging } \\
\text { the cell structure. }\end{array}$ & [86] \\
\hline Ag NPs & Parkinsonia florida & $10-15$ & $\begin{array}{l}\text { Staphylococcus aureus } \\
\text { Escherichia coli }\end{array}$ & $\begin{array}{c}12.5 \\
11.7 \\
10.5 \\
7.8 \\
6.5 \\
5\end{array}$ & $\begin{array}{l}8 \mu \mathrm{g} / \mu \mathrm{L} \\
4 \mu \mathrm{g} / \mu \mathrm{L} \\
2 \mu \mathrm{g} / \mu \mathrm{L}\end{array}$ & $\begin{array}{c}\mathrm{Ag}^{+} \text {from } \mathrm{Ag} \text { NPs acts as antibacterial } \\
\text { agents }\end{array}$ & [87] \\
\hline $\mathrm{Cu}$ NPs & Eryngium caucasicum & $0-40$ & $\begin{array}{c}\text { Escherichia coli } \\
\text { Salmonella } \\
\text { typhimurium, } \\
\text { Bacillus cereus } \\
\text { Staphylococcus aureus }\end{array}$ & $\begin{array}{l}23.3 \pm 0.12 \\
23.1 \pm 0.08 \\
21.3 \pm 0.22 \\
21.1 \pm 0.16\end{array}$ & $50 \mu \mathrm{L}$ & $\begin{array}{l}\text { The thick cell walls of gram-positive } \\
\text { prevent the penetration of } \mathrm{Cu} \text { NPs. } \\
\text { While thin peptidoglycan layer of the } \\
\text { gram-negative bacteria attract more } \\
\mathrm{Cu}^{2+} \text {, which leads to bactericidal } \\
\text { activity. }\end{array}$ & {$[88]$} \\
\hline $\mathrm{Cu}$ NPs & Syzygiumaromaticum & $\sim 20$ & $\begin{array}{l}\text { Staphylococcus spp. } \\
\text { Pseudomonas spp. }\end{array}$ & $\begin{array}{c}4 \pm 1.0 \\
5 \pm 1.0 \\
5 \pm 1.0 \\
6 \pm 1.0 \\
3 \pm 1.0 \\
4 \pm 1.0 \\
5 \pm 1.0 \\
5 \pm 1.0 \\
5 \pm 1.0 \\
6 \pm 1.0 \\
6 \pm 1.0 \\
7 \pm 1.0 \\
6 \pm 1.0 \\
7 \pm 1.0 \\
8 \pm 1.0 \\
8 \pm 1.0 \\
14 \pm 0.15 \\
18 \pm 0.35 \\
20 \pm 0.55 \\
22 \pm 0.76 \\
15 \pm 0.18 \\
19 \pm 0.24 \\
21 \pm 0.57 \\
23 \pm 0.89\end{array}$ & $\begin{array}{l}100 \mu \mathrm{L} \\
150 \mu \mathrm{L} \\
200 \mu \mathrm{L} \\
250 \mu \mathrm{L}\end{array}$ & $\begin{array}{l}\mathrm{Cu} \text { NPs penetrate into cell, generate } \\
\text { ROS, which interacts and disrupts } \\
\text { DNA, enzymes, and transport chains. } \\
\text { Leaking the cell membrane and } \\
\text { consequently, cell death. }\end{array}$ & [89] \\
\hline
\end{tabular}


antibacterial activity against several bacterial species. Zada et al. extracted gold nanoparticles using the cellfree extract of cyanobacterium Leptolyngbya JSC-1 and verifies their antibacterial activity against two common pathogens $E$. coli and $S$. aureus. They reported that $\mathrm{Au}$ NPs exhibit good antibacterial activity against $E$. coli, with the zone of inhibition approximately $18 \pm$ $2 \mathrm{~mm}$ and $14 \pm 2 \mathrm{~mm}$ for $S$. aureus, in well diffusion assay [34]. Black lemon extract derived Au NPs used against Gram-positive (Staphylococcus aureus) and Gram-negative (Pseudomonas aeruginosa) for their antibacterial assessment at three different concentrations $(25,50$, and $100 \mu \mathrm{L})$ [83]. The results show that the gold nanoparticles exhibit strong antibacterial activity on gram-positive bacteria than the gram-negative bacteria used in this study. Also, the maximum diameter of the zone of inhibition (about $22 \mathrm{~mm}$ ) observed around $S$. aureus bacterium at 100 $\mu \mathrm{L}$ [83]. Sujatha et al. (2019) performed antimicrobial efficacy of the Catharanthus roseus generated gold nanoparticles against several pathogenic bacteria using the agar well diffusion method at two concentrations $(15,30 \mu \mathrm{L})$. The observation shows maximum inhibitory effect against Aeromonas liquefaciens $>$ Enterococcus fecalis $>$ Salmonella typhimurium $>$ Micrococcus luteus at $15 \mu \mathrm{L}$. Somehow, at $30 \mu \mathrm{L}$ of gold nanoparticles, the sequence of the inhibitory effect changes slightly, i.e., Aeromonas liquefaciens $>$ Micrococcus luteus $>$ Enterococcus fecalis $>$ Salmonella typhimurium [84]. Among other metallic nanoparticles Au NPs have effective antimicrobial actiivity due to its tremendously large surface area to mass ratio, which provides much better exposure with microorganisms.

\section{Antimicrobial activity of silver nanoparticles}

Various studies conducted confirming the antibacterial activity of biologically synthesized silver nanoparticles. The silver nanoparticles of Ajuga parviflora used against Gram-positive (B. subtilis, $S$. aureus) and Gram-negative (E. coli, P. aeruginosa) to check their antimicrobial activity using a well diffusion assay. The clear zone of inhibition around wells at $75 \mu \mathrm{L}$ and $100 \mu \mathrm{L}$ concentrations shows that Ag NPs exhibit antibacterial activity. The maximum inhibitory effect with $14.58 \pm 0.41 \mathrm{~mm}$ of the zone of inhibition reported against Staphylococcus aureus at $100 \mu \mathrm{L}$ and a minimum of $13.96 \pm 0.62 \mathrm{~mm}$ against $E$. coli [85]. Bragais et al. demonstrated that Hydnocarpus alcalae synthesized Ag NPs exhibited significant bactericidal activity against $E$. coli and $S$. aureus. The observed size of the zone of inhibition due to $1 \mu \mathrm{g}$ of $H$. alcalae was $10 \mathrm{~mm}$ for both pathogenic species [86]. Millán et al. assessed the antimicrobial activity of P. floridamediated silver nanoparticles against human pathogenic bacteria $S$. aureus and E. coli. 2, 4, and $8 \mu \mathrm{g} / \mu \mathrm{L}$ of Ag NPs were loaded on Whatman filter paper disks to perform the antimicrobial assay. The measurements of the zone of inhibition show that Ag NPs exhibited good antibacterial activity against $S$. aureus than E. coli [87]. We have seen that Ag NPs showed significant antimicrobial activity so Ag NPs might be a good source to develop as antimicrobial agent against the multidrug-resistant pathogens.

\section{Antimicrobial activity of copper nanoparticles}

Copper nanoparticles ( $\mathrm{Cu}$ NPs) got prestigious concentration due to their distinctive optical, electrical, and magnetic properties. Moreover, $\mathrm{Cu}$ NPs exhibit strong antibacterial properties against grampositive and gram-negative pathogenic bacteria. The antibacterial properties of $\mathrm{Cu}$ NPs depend on their size, high surface area, and stability. Hasheminya et al. investigate the antibacterial efficacy of copper nanoparticles of E.caucasicum leaves extract. The results proved the strong antibacterial activity of E.caucasicum $\mathrm{Cu}$ NPs against the Gram-negative bacteria (E. coli, S. typhimurium) as compared to the Gram-positive bacteria (B. cereus and $S$. aureus) [88]. Rajesh et al. demonstrated the bactericidal activity of $S$. aromaticum-mediated $\mathrm{Cu}$ NPs against pathogenic bacteria. The biosynthesized Cu NPs loaded on the discs of Whatman's filter paper no. 1 with four different concentrations. The results of the study reveal the antibacterial effect of $\mathrm{Cu}$ NPs [76]. $\mathrm{Cu}$ NPs of Curcuma longa were treated against $B$. subtilis and $E$. coli to study their antibacterial activity. The $\mathrm{Cu}$ NPs show a strong antibacterial against Gram-positive bacteria than Gram-negative bacteria [89]. The antibacterial effects of $\mathrm{Cu}$ NPs are found to be even higher than that of gold nanoparticles. Also, the synthesized copper nanoparticles demonstrated antifungal activity against candida species. In the emerging field of nanotechnology, copper oxides nanoparticles are considered to be one of the most effective antimicrobial agents.

\section{Anticancer activity of biosynthesized nanoparticles}

Biosynthesized nanoparticles and their various 
biomedical application is now a vastly growing field, like antibacterial, antioxidants and anticancer activity. In this review, we observed the anticancer activity of some biosynthesized NPs ( $\mathrm{Au}, \mathrm{Ag}$, and $\mathrm{Cu}$ ) (Table 6). Now it is a fact that cancer is a disease caused by various factors and effected by some genetic and environmental factors. Some anticancer drugs are not sufficient to reach the target site and effectively do their pharma logical activity [90]. The characteristics of metal NPs such as ease of synthesis, high surface to volume ratio, and broad optical property, offer some opportunity for cancer treatment [90]. For the evaluation of anticancer activity in various cell lines, different types of assays performed, but in this review, we are going to analyze the results of MTT assay, which is used to describe the metabolic function and health of cells. This assay is mainly for the endpoint analysis [91].

\section{Anticancer activity of Ag NPs}

Various research indicate the high potential of $\mathrm{Ag}$ NPs as an anticancer agent. In research in which $\mathrm{Ag}$ NPs are biosynthesized by a culture medium of E.coli spp and evaluated for their anticancer activity, very promising results came out. In vitro cytotoxic activity of Ag NPs against A549 and Hep G2 cell lines and to check this anticancer activity MTT Assay is developed, silver nanoparticles are compared with a standard known as cyclophosphamide [92]. The results have shown that the Ag NPs reduce the cell viability of some cancer cell lines. These results were dependent on the dose. The MIC values studied at $1 \mathrm{mg}$ of $\mathrm{Ag}$
NPs against cancer cell lines and HIC at $100 \mathrm{mg}$ and $50 \mathrm{mg}$. The concentration for $50 \%$ of cell death for both the cell lines is at 50 and $100 \mathrm{mg}$, respectively [92]. In another research where Ag NPs produced from Panax ginseng Meyer leaves extract shown great cytotoxic effects against the A549, MCF7, and HepG2 cell lines. The exact measurement found out at $2.5 \mathrm{mg} /$ $\mathrm{mL}$ has much higher effectiveness for MCF7 cell line then A549 and HepG2 cell lines. And the toxicity is reduced at $5 \mathrm{mg}$ and $10 \mathrm{mg}$ concentrations [93]. Silver nanoparticles are promising anticancer agents because they influence the cell cycle, inhibit cancer cell proliferation, induce oxidative stress, and propagate programmed cellular death.

\section{Anticancer activity of Au NPs}

The cytotoxic activity of biosynthesized Au NPs is very much significant. In research, the Cystoseira baccata extract generated Au NPs tested against human colon cell lines, which includes Caco-2, HT-29 and on a healthy cell line PCS-201-010CRC. After the analysis, there was no effect of $\mathrm{CB}$ extract on two cell lines Caco2 and PCS-201-010, while for the HT-29, there was some effect at $1 \mathrm{~g} / \mathrm{mL}$. While on the other hand, Au NPs showed a very visible cytotoxic effect in the Caco-2 cell line, this is also dose-dependent research, and various doses were from 400-200-100$50 \mathrm{mg}$. The cell viability percentages were $38.72 \pm$ $1.56 \%, 39.98 \pm 1.815 \%, 46.67 \pm 4.42 \%$, and $49.85 \pm$ $6.98 \%$, respectively. A significant cytotoxic effect was also detected in HT-29 at all doses, with the following percentages of cell viability: $11.75 \pm 3.94 \%, 12.87 \pm$

Table 6 Summary of anti-cancer activity of metallic nanoparticles

Anticancer activity of biosynthesized metallic nanoparticles

\begin{tabular}{|c|c|c|c|c|c|}
\hline Source & Metalic NPs & Testing method & Activity against & Analysis & Reference \\
\hline E. coli $\mathrm{sp}$ & Ag NPs & MTT assay & A549 and Hep G2 & $\begin{array}{l}50 \% \text { of cell death for both the } \\
\text { cell lines are at } 50 \text { and } 100 \mathrm{mg}\end{array}$ & {$[92]$} \\
\hline $\begin{array}{l}\text { Panax } \\
\text { ginseng Meyer }\end{array}$ & Ag NPs & MTT assay & A549, MCF7 and HepG2 cell lines & $\begin{array}{l}2.5 \mathrm{mg} / \mathrm{mL} \text { have the much higher effectivness for } \\
\text { MCF7 cell line then A549 and HepG2 cell lines. }\end{array}$ & [93] \\
\hline $\begin{array}{l}\text { Cystoseira } \\
\text { baccata }\end{array}$ & $\mathrm{Au}$ NPs & MTT assay & $\begin{array}{l}\text { Caco-2 and HT-29 and also on a } \\
\text { healthy cell line PCS-201-010CRC }\end{array}$ & $\begin{array}{c}\text { All doses, with the following percentages of cell } \\
\text { viability: } 11.75 \pm 3.94 \%, 12.87 \pm 0.36 \\
18.98 \pm 3.57,25.8 \pm 7.29 \% \text { and } 21.74 \pm 5.3\end{array}$ & {$[72]$} \\
\hline $\begin{array}{l}\text { Abies } \\
\text { spectabilis }\end{array}$ & $\mathrm{Au}$ NPs & MTT assay & T24 cell line & $\begin{array}{l}\text { The } 50 \% \text { IC effect is } \\
\text { around } 15 \text { to } 20 \mu \mathrm{g} / \mathrm{mL}\end{array}$ & {$[94]$} \\
\hline Brown algae & $\mathrm{Cu} \mathrm{NPs}$ & MTT assay & $\begin{array}{l}\text { MCF7 Breast } \\
\text { cancer cell lines }\end{array}$ & $\begin{array}{l}\text { The MC of copper } 100 \mu \mathrm{g} / \mathrm{mL} \\
\text { nhibited the growth by } 93 \%\end{array}$ & {$[95]$} \\
\hline O. cochinchinense & $\mathrm{Cu}$ NPs & MTT assay & $\begin{array}{l}\text { HCT-116 human } \\
\text { colon cancer cell line }\end{array}$ & $\begin{array}{l}\text { IC50 is from } 40 \mu \mathrm{g} / \mathrm{mL} \text {; the cell viability was } \\
\text { reduced to } 22 \% \text { when the concentration } \\
\text { increased gradually. }\end{array}$ & [96] \\
\hline
\end{tabular}


$0.36,18.98 \pm 3.57,25.8 \pm 7.29 \%$, and $21.74 \pm 5.3 \%$ [72]. In another research, the biosynthesized $\mathrm{Au}$ NPs from $A$. spectabilis extracts shown a significant cytotoxic effect on bladder cancer cells' T24 cell line by MTT assay. The effect is measured and found out that the reduction of viability of T24 cells in a dosedependent order. The $50 \%$ IC effect is around 15 to 20 $\mu \mathrm{g} / \mathrm{mL}$, respectively [94]. Gold nanoparticles absorb incident photons and convert them to heat to destroy cancer cells. Hence, further research on this may lead to the development of novel anticancer drugs which can be used to combat cancer.

\section{Anticancer activity of Cu NPs}

The anticancer activity of $\mathrm{Cu}$ NPs also evaluated in various research. In a research done in 2019, the cytotoxicity of $\mathrm{Cu}$ NPs, which were biosynthesized by brown algae, was checked against MCF7 Breast cancer cell lines, this is also a dose-dependent concentration from 6.5 to $100 \mu \mathrm{g} / \mathrm{mL}$. The IC 50 value to $\mathrm{Cu}$ NPs was at $61.25 \mu \mathrm{g} / \mathrm{mL}$. The MC of copper 100 $\mu \mathrm{g} / \mathrm{mL}$ inhibited the growth by $93 \%$ [95]. The green synthesis of $\mathrm{Cu}$ NPs by $O$. cochinchinense studied for their cytotoxic activity against HCT-116 human colon cancer cell line. MTT assay performed. This is also a dose-dependent study from 10-20-30-40-60-80 and $100 \mu \mathrm{g} / \mathrm{mL}$. The cytotoxicity on the cell line for IC50 is from $40 \mu \mathrm{g} / \mathrm{mL}$. The cell viability was reduced to $22 \%$ when the concentration increased gradually [96]. Recent advances related to the biomedical application of $\mathrm{Cu}$ NPs, with a focus on cancer imaging and therapy are considered to be one of the most effective anticancer agents.

\section{Conclusions and Future Challenges}

Nanotechnology has numerous applications in various domains of biological fields from targeted gene/drug delivery, antimicrobial activity, anticancer therapy, bio imaging, bio sensing, etc. The nanoparticles are applicable in biomedical and pharmaceutics due to their extraordinary size, shape, and surface area. Nanoparticles synthesized by physical or chemical method requires high energy and generate toxic by-products that are harmful to the environment. In recent years, nanoparticles synthesis by green approach proves very advantageous as it is an eco-friendly, sot-effective, and rapid process. Metallic nanoparticles generated by microbes and different parts of plants got a prestigious place in biotechnology applications, including antibacterial and Anticancer activity. Metallic ( $\mathrm{Ag}, \mathrm{Au}, \mathrm{Cu})$ nanoparticles can be used as nano medicines against antimicrobial resistance bacteria to prevent the growth of pathogenic microbes. The target-specific delivery and large surface-toarea ratio of metallic nanoparticles allow the loading of Anticancer drugs, hence a potent agent for cancer therapy. Biologically synthesized nanoparticles show positive characterization results, as similar to synthetic metallic nanoparticles, including UV-Vis, FTIR, XRD, SEM, and TEM. In the future, green synthesized nanoparticles can be the treatment of severe diseases in the form of nano medicines. There are potential benefits and impacts of nanobiotechnology in various biomedical applications and prospects. Till date the challenges that this field is facing during green synthesis of NPs can be concluded as follows, the synthesis of the nanoparticles of specific morphology including shape and size by this method requires more optimization. For biomedical applications synthesis of nanoparticles with certain physiochemical characteristics requires more evaluation of their properties. The mechanical aspect which is very important for fabrication of NPs by this method needs further investigation. As we know there are certain metabolites involved in the biological filtrates must be investigated for each compound in nanoparticles fabrication. Another major challenge is the scaling up approach by this method and it is a big hurdle for its commercialization. Viable NPs and the stability with higher yield depends upon the factors like temperature, $\mathrm{pH}$, salt concentration, contact time needs more evaluation.

\section{Acknowledgements}

Authors gratefully acknowledge all the respective departments for their favors

\section{Authors' contributions}

Tayab Shafiq, Mohammad Uzair, and M Junaid designed the study. Tayab Shafiq, Mohammad Uzair, and $\mathrm{M}$ Junaid. contributed to the literature search, drew the figures and co-wrote the paper. Mohsin Zafar, S. Jawad and S. Alasar contributed their experiences and revised the manuscript. All authors read and approved the final manuscript.

\section{Conflict of Interests}

The authors declare that no competing interest exists. 


\section{References}

[1] I. Khan, K. Saeed, I. Khan. Nanoparticles: Properties, applications and toxicities. Arabian Journal of Chemistry. 2019, 12(7): 908-931.

[2] G. Sharma, A. Kumar, S. Sharma, et al. Novel development of nanoparticles to bimetallic nanoparticles and their composites: a review. Journal of King Saud University-Science. 2019, 31(2): 257-269.

[3] R.M. Kumari, R. Goswami, S. Nimesh. Application of Nanotechnology in Diagnosis and Therapeutics. Nanotechnology for Energy and Environmental Engineering: Springer; 2020: 413-440.

[4] K. McNamara, S.A. Tofail. Nanoparticles in biomedical applications. Advances in Physics: X. 2017, 2(1): 54-88.

[5] G.Z. Gayda, O.M. Demkiv, N.Y. Stasyuk, et al. Metallic nanoparticles obtained via "green" synthesis as a platform for biosensor construction. Applied Sciences. 2019, 9(4): 720 .

[6] R. Razavi, R. Molaei, M. Moradi, et al. Biosynthesis of metallic nanoparticles using mulberry fruit (Morus alba L.) extract for the preparation of antimicrobial nanocellulose film. Applied Nanoscience. 2020, 10(2): 465-476.

[7] J.A.Elegbede, A. Lateef, M.A. Azeez, et al. Biofabrication of gold nanoparticles using xylanases through valorization of corncob by Aspergillus niger and Trichoderma longibrachiatum: antimicrobial, antioxidant, anticoagulant and thrombolytic activities. Waste and Biomass Valorization. 2020, 11(3): 781-791.

[8] A. Gour, N.K. Jain. Advances in green synthesis of nanoparticles. Artificial cells, nanomedicine, and biotechnology. 2019, 47(1): 844-851.

[9] O.V. Kharissova, B.I. Kharisov, C.M. Oliva González, et al. Greener synthesis of chemical compounds and materials. Royal Society Open Science. 2019, 6(11): 191378.

[10] S. Ahmed, Saifullah, M. Ahmad, et al. Green synthesis of silver nanoparticles using Azadirachta indica aqueous leaf extract. Journal of radiation research and applied sciences. 2016, 9(1): 1-7.

[11] J. Singh, T. Dutta, K.H. Kim, et al. 'Green'synthesis of metals and their oxide nanoparticles: applications for environmental remediation. Journal of nanobiotechnology. 2018; 16(1): 84 .

[12] K.S. Siddiqi, A. Husen, R.A. Rao. A review on biosynthesis of silver nanoparticles and their biocidal properties. Journal of nanobiotechnology. 2018, 16(1): 14.

[13] D. Sharma, S. Kanchi, K. Bisetty. Biogenic synthesis of nanoparticles: a review. Arabian journal of chemistry. 2019, 12(8): 3576-3600.

[14] A.K. Shukla, S. Iravani. Metallic nanoparticles: green synthesis and spectroscopic characterization. Environmental Chemistry Letters. 2017, 15(2): 223-231.

[15] M. Ovais, A.T. Khalil, M. Ayaz, et al. Biosynthesis of metal nanoparticles via microbial enzymes: a mechanistic approach. International journal of molecular sciences. 2018, 19(12): 4100.

[16] Y.N. Slavin, J. Asnis, U.O. Häfeli, et al. Metal nanoparticles: understanding the mechanisms behind antibacterial activity. Journal of nanobiotechnology. 2017, 15(1): 65.

[17] R. Subbaiya, M. Saravanan, A.R. Priya, et al. Biomimetic synthesis of silver nanoparticles from Streptomyces atrovirens and their potential anticancer activity against human breast cancer cells. IET nanobiotechnology. 2017, 11(8): 965-972.

[18] P. Dauthal, M. Mukhopadhyay. Noble metal nanoparticles: plant-mediated synthesis, mechanistic aspects of synthesis, and applications. Industrial \& Engineering
Chemistry Research. 2016; 55(36): 9557-9577.

[19] N. Marooufpour, M. Alizadeh, M. Hatami, et al. Biological Synthesis of Nanoparticles by Different Groups of Bacteria. Microbial Nanobionics: Springer; 2019, 63-85.

[20] A. Fariq, T. Khan, A. Yasmin. Microbial synthesis of nanoparticles and their potential applications in biomedicine. Journal of Applied Biomedicine. 2017, 15(4): 241-248.

[21] P. Singh, Y.J. Kim, D. Zhang, et al. Biological synthesis of nanoparticles from plants and microorganisms. Trends in biotechnology. 2016, 34(7): 588-599.

[22] R. Abbai, J.M. Ramya Mathiyalagan, Y.J. Kim, et al. Green synthesis of multifunctional silver and gold nanoparticles from the oriental herbal adaptogen: Siberian ginseng. International journal of nanomedicine. 2016, 11: 3131.

[23] P. Singh, S. Pandit, J. Garnæs, et al. Green synthesis of gold and silver nanoparticles from Cannabis sativa (industrial hemp) and their capacity for biofilm inhibition. International journal of nanomedicine. 2018, 13: 3571.

[24] C. Kohout, C. Santi, L. Polito. Anisotropic gold nanoparticles in biomedical applications. International journal of molecular sciences. 2018, 19(11): 3385.

[25] K. Sztandera, M. Gorzkiewicz, B. Klajnert-Maculewicz. Gold nanoparticles in cancer treatment. Molecular pharmaceutics. 2018, 16(1): 1-23.

[26] R. Herizchi, E. Abbasi, M. Milani, et al. Current methods for synthesis of gold nanoparticles. Artificial cells, nanomedicine, and biotechnology. 2016, 44(2): 596- 602.

[27] N. Elahi, M. Kamali, M.H. Baghersad. Recent biomedical applications of gold nanoparticles: A review. Talanta. 2018, 184: 537-556.

[28] S. Valsalam, P. Agastian, G.A. Esmail, et al. Biosynthesis of silver and gold nanoparticles using Musa acuminata colla flower and its pharmaceutical activity against bacteria and anticancer efficacy. Journal of Photochemistry and Photobiology B: Biology. 2019, 201: 111670.

[29] H. Singh, J. Du, P. Singh, et al. Ecofriendly synthesis of silver and gold nanoparticles by Euphrasia officinalis leaf extract and its biomedical applications. Artificial cells, nanomedicine, and biotechnology. 2018, 46(6): 11631170.

[30] S. Francis, E.P. Koshy, B. Mathew. Green synthesis of Stereospermum suaveolens capped silver and gold nanoparticles and assessment of their innate antioxidant, antimicrobial and antiproliferative activities. Bioprocess and biosystems engineering. 2018, 41(7): 939-951.

[31] J. Chan, R.R. Ali, K. Shameli, et al. Green Synthesis of Gold Nanoparticles using Aqueous Extract of Clitoria Ternatea Flower. 2020.

[32] N.Y. Nadaf, .SS. Kanase. Biosynthesis of gold nanoparticles by Bacillus marisflavi and its potential in catalytic dye degradation. Arabian Journal of Chemistry. 2019, 12(8): 4806-4814.

[33] Y.M. Patil, S.N. Rajpathak, D.D. Deobagkar. Characterization and DNA methylation modulatory activity of gold nanoparticles synthesized by Pseudoalteromonas strain. Journal of biosciences. 2019, 44(1): 15.

[34] S. Zada, A. Ahmad, S. Khan, et al. Biofabrication of gold nanoparticles by Lyptolyngbya JSC-1 extract as super reducing and stabilizing agents: Synthesis, characterization and antibacterial activity. Microbial pathogenesis. 2018, 114:116-123.

[35] M.M. Abdel-Kareem, A. Zohri. Extracellular mycosynthesis of gold nanoparticles using Trichoderma hamatum: optimization, characterization and antimicrobial activity. Letters in applied microbiology. 2018, 67(5): 465-475. 
[36] M.A. Mohamed. Myco-engineered gold nanoparticles from Jahnula aquatica coated with ampicillin/amoxicillin and their antibacterial and anticancer activity against cancer cells. Biotechnology letters. 2020, 42(1): 151-170.

[37] M. Manikandakrishnan, S. Palanisamy, M. Vinosha, et al. Facile green route synthesis of gold nanoparticles using Caulerpa racemosa for biomedical applications. Journal of Drug Delivery Science and Technology. 2019, 54: 101345.

[38] X.F. Zhang, Z.G. Liu, W. Shen, et al. Silver nanoparticles: synthesis, characterization, properties, applications, and therapeutic approaches. International journal of molecular sciences. 2016, 17(9): 1534.

[39] A.K. Keshari, R. Srivastava, S. Yadav, et al. Synergistic Activity of Green Silver Nanoparticles with Antibiotics. Methods. 2020, 20(21): 30.

[40] P. Mathur, S. Jha, S. Ramteke, et al.. Pharmaceutical aspects of silver nanoparticles. Artificial cells, nanomedicine, and biotechnology. 2018, 46(sup1): 115126.

[41] S.H. Lee, B.H. Jun. Silver Nanoparticles: Synthesis and application for nanomedicine. International journal of molecular sciences. 2019, 20(4): 865.

[42] E. Baltazar-Encarnación, C.E. Escárcega-González, X.G. Vasto-Anzaldo, et al. Silver Nanoparticles Synthesized through Green Methods Using Escherichia coli Top 10 (Ec-Ts) Growth Culture Medium Exhibit Antimicrobial Properties against Nongrowing Bacterial Strains. Journal of Nanomaterials. 2019, 2019.

[43] A. Salaam, B.C. Adebayo-Tayo, A. Ajibade. Phycosynthesis of Silver Nanoparticles Using Chlorella vulgaris Metabolites: Its Antibacterial, Anti-Biofilm and In-Vitro Cytotoxicity Potential and Effect of Optimized Conditions on Biosynthesis. African Journal of Biomedical Research. 2020, 23(1): 17-23.

[44] M. Saravanan, S.K. Barik, D. MubarakAli, et al. Synthesis of silver nanoparticles from Bacillus brevis (NCIM 2533) and their antibacterial activity against pathogenic bacteria. Microbial pathogenesis. 2018, 116: 221-226.

[45] A. Abdel-Azeem, A.A. Nada, A. O'Donovan, et al. Mycogenic silver nanoparticles from endophytic trichoderma atroviride with antimicrobial activity. 2020.

[46] F.N. Spagnoletti, C. Spedalieri, F. Kronberg, et al. Extracellular biosynthesis of bactericidal $\mathrm{Ag} / \mathrm{AgCl}$ nanoparticles for crop protection using the fungus Macrophomina phaseolina. Journal of environmental management. 2019, 231: 457-466.

[47] S.O. Aisida, K. Ugwu, P.A. Akpa, et al. Morphological, optical and antibacterial study of green synthesized silver nanoparticles via Vernonia amygdalina. Materials Today: Proceedings. 2020.

[48] A. Almatroudi, H. Khadri, M. Azam, et al. Antibacterial, Antibiofilm and Anticancer Activity of Biologically Synthesized Silver Nanoparticles Using Seed Extract of Nigella sativa. Processes. 2020, 8(4): 388.

[49] S.J. bakht Dalir, H. Djahaniani, F. Nabati, et al. Characterization and the evaluation of antimicrobial activities of silver nanoparticles biosynthesized from Carya illinoinensis leaf extract. Heliyon. 2020, 6(3): e03624.

[50] M.I. Din, F. Arshad, Z. Hussain, et al. Green adeptness in the synthesis and stabilization of copper nanoparticles: catalytic, antibacterial, cytotoxicity, and antioxidant activities. Nanoscale research letters. 2017, 12(1): 638.

[51] H. Zhao, H. Su, A. Ahmeda, et al. Biosynthesis of copper nanoparticles using Allium eriophyllum Boiss leaf aqueous extract; characterization and analysis of their antimicrobial and cutaneous wound-healing potentials. Applied Organometallic Chemistry. 2020: e5587.

[52] K. Seku, B. Reddy Ganapuram, B. Pejjai, et al. Hydrothermal synthesis of Copper nanoparticles, characterization and their biological applications. International Journal of Nano Dimension. 2018, 9(1): 7-14.

[53] K. Kiran, S. Rajeshkumar, A. Roy, et al. In vitro cytotoxic Effects of Copper Nanoparticles Synthesized from Avocado Seed Extract. Indian Journal of Public Health Research \& Development. 2019, 10(11).

[54] E. Ituen, E. Ekemini, L. Yuanhua, et al. Mitigation of microbial biodeterioration and acid corrosion of pipework steel using Citrus reticulata peels extract mediated copper nanoparticles composite. International Biodeterioration \& Biodegradation. 2020, 149: 104935.

[55] P.E. Das, I.A .Abu-Yousef, A.F. Majdalawieh, et al. Green Synthesis of Encapsulated Copper Nanoparticles Using a Hydroalcoholic Extract of Moringa oleifera Leaves and Assessment of Their Antioxidant and Antimicrobial Activities. Molecules. 2020, 25(3): 555.

[56] E.Z. Gomaa, M.M. Housseiny, A.A.A.K. Omran. Fungicidal efficiency of Silver and copper nanoparticles produced by Pseudomonas fluorescens ATCC 17397 against four Aspergillus species: a molecular study. Journal of Cluster Science. 2019, 30(1): 181-196.

[57] B.T. Abd-Elhalim, G. R.F., A.T. Kh A, et al. Biosynthesis of Copper nanoparticles using bacterial supernatant optimized with certain agro-industrial byproducts. Novel Research in Microbiology Journal. 2019, 3(6): 558-578.

[58] M. Noman, M. Shahid, T. Ahmed, et al. Use of biogenic copper nanoparticles synthesized from a native Escherichia sp. as photocatalysts for azo dye degradation and treatment of textile effluents. Environmental Pollution. 2020, 257: 113514.

[59] M. Noman, M. Shahid, T. Ahmed, et al. Green copper nanoparticles from a native Klebsiella pneumoniae strain alleviated oxidative stress impairment of wheat plants by reducing the chromium bioavailability and increasing the growth. Ecotoxicology and Environmental Safety. 2020, 192: 110303 .

[60] T. Akther, V. Mathipi, N.S. Kumar, et al. Fungal-mediated synthesis of pharmaceutically active silver nanoparticles and anticancer property against A549 cells through apoptosis. Environmental Science and Pollution Research. 2019, 26(13): 13649-13657.

[61] B. Akbari, M.P. Tavandashti, M. Zandrahimi. Particle size characterization of nanoparticles-a practicalapproach. Iranian Journal of Materials Science and Engineering. 2011, 8(2): 48-56.

[62] S. Ali, Y. Khan, Y. Iqbal, et al. Size determination of gold nanoparticles in silicate glasses by UV-Vis spectroscopy. Journal of Nanophotonics. 2017, 11(1): 016011.

[63] M.A. Mohamed, J. Jaafar, A. Ismail, et al. Fourier transform infrared (FTIR) spectroscopy. Membrane Characterization: Elsevier; 2017: 3-29.

[64] A.D. Gupta, S. Karthikeyan. Individual and combined toxic effect of nickel and chromium on biochemical constituents in E. coli using FTIR spectroscopy and Principle component analysis. Ecotoxicology and environmental safety. 2016, 130: 289-294.

[65] B. Kumar, K. Smita, L. Cumbal, et al. Green synthesis of silver nanoparticles using Andean blackberry fruit extract. Saudi journal of biological sciences. 2017, 24(1): 45-50.

[66] G. Lakshmanan, A. Sathiyaseelan, P. Kalaichelvan, et al. Plant-mediated synthesis of silver nanoparticles using fruit extract of Cleome viscosa L.: Assessment of their antibacterial and anticancer activity. Karbala International Journal of Modern Science. 2018, 4(1): 6168.

[67] V. Dhand, L. Soumya, S. Bharadwaj, et al. Green synthesis of silver nanoparticles using Coffea arabica seed extract and its antibacterial activity. Materials Science and Engineering: C. 2016, 58: 36-43.

[68] H.A. Rehab, M. Mostafa, H.I. Eman, et al. 
Green Synthesis of Silver Nanoparticles Using Psidumguajavaleaf Extract. Journal of Environmental Science. 2019, 46(1): 1-19.

[69] S. Rajeshkumar. Anticancer activity of eco-friendly gold nanoparticles against lung and liver cancer cells. Journal of Genetic Engineering and Biotechnology. 2016, 14(1): 195-202.

[70] H. Shabestarian, M. Homayouni-Tabrizi, M. Soltani, et al. Green synthesis of gold nanoparticles using Sumac aqueous extract and their antioxidant activity. Materials Research. 2017, 20(1): 264-270.

[71] M. Ramakrishna, D.R. Babu, R.M. Gengan, et al. Green synthesis of gold nanoparticles using marine algae and evaluation of their catalytic activity. Journal of Nanostructure in Chemistry. 2016, 6(1): 1-13.

[72] N. González-Ballesteros, S. Prado-López, J. RodríguezGonzález, et al. Green synthesis of gold nanoparticles using brown algae Cystoseira baccata: Its activity in colon cancer cells. Colloids and Surfaces B: Biointerfaces. 2017, 153: 190-198.

[73] J. Yu, D. Xu, H.N. Guan, C. Wang, L.K. Huang. Facile one-step green synthesis of gold nanoparticles using Citrus maxima aqueous extracts and its catalytic activity. Materials Letters. 2016, 166: 110-112.

[74] Z. Molnár, V. Bódai, G. Szakacs, et al. Green synthesis of gold nanoparticles by thermophilic filamentous fungi. Scientific reports. 2018, 8(1): 1-12.

[75] A. Olajire, N. Ifediora, M. Bello, et al. Green synthesis of copper nanoparticles using Alchornea laxiflora leaf extract and their catalytic application for oxidative desulphurization of model oil. Iranian Journal of Science and Technology, Transactions A: Science. 2018, 42(4): 1935-1946.

[76] K. Rajesh, B. Ajitha, Y.A.K. Reddy, et al. Assisted green synthesis of copper nanoparticles using Syzygium aromaticum bud extract: Physical, optical and antimicrobial properties. Optik. 2018; 154: 593-600.

[77] I.M. Chung, A. Abdul Rahuman, S. Marimuthu, et al. Green synthesis of copper nanoparticles using Eclipta prostrata leaves extract and their antioxidant and cytotoxic activities. Experimental and therapeutic medicine. 2017, 14(1): 18-24.

[78] N. Nagar, V. Devra. Green synthesis and characterization of copper nanoparticles using Azadirachta indica leaves. Materials Chemistry and Physics. 2018, 213: 44-51.

[79] W.H. Organization. Antibiotic resistance. 2020.

[80] I .United. No Time to Wait-Securing the Future from Drug-resistant Infections. Report to the Secretary General of the Nations. 2019.

[81] A. Lateef, J.A. Elegbede, P.O. Akinola, et al. Biomedical Applications Of Green Synthesized-Metallic NanoParticles: A Review. 2019.

[82] L. Wang, C. Hu, L.J. Ijon Shao. The antimicrobial activity of nanoparticles: present situation and prospects for the future. 2017, 12: 1227.

[83] M.S. Mahdi, A. Parveen. Biosynthesis, Characterization and Antibacterial Activity of Gold Nanoparticles (AuNPs) using Black Lemon Extract. Materials Today: Proceedings. 2019, 18: 5164-5169.

[84] R. Sujatha, D. Iswarya. The Biosynthesis Of Catharanthus Roseus Leaves Based Gold Nanoparticles (Aunps) And Their Antimicrobial And Anticancer Applications. 2019.

[85] A. Kandwal, M. Purohit, A.K. Khajuria, et al. Green
Synthesis, Characterization And Antimicrobial Activity Of Silver Nanoparticles Using Leaf Extract Of Ajuga Parviflora Benth. In Wall. 2019, 19(2): 762-768.

[86] E.K. Bragais, L.M. Labaclado. Green Synthesis, Characterization and Antimicrobial Activity of Silver Nanoparticles Using Dudoa (Hydnocarpus alcalae C. DC.) Leaf Extract As a Reducing and Stabilizing Agent. Current Nanomaterials. 2019, 4(2): 112-124.

[87] A. López-Millán, C.L. Del Toro-Sánchez, J.R. RamosEnríquez, et al. Biosynthesis of gold and silver nanoparticles using Parkinsonia florida leaf extract and antimicrobial activity of silver nanoparticles. Materials Research Express. 2019, 6(9): 095025.

[88] S.M. Hasheminya, J. Dehghannya. Green synthesis and characterization of copper nanoparticles using Eryngium caucasicum Trautv aqueous extracts and its antioxidant and antimicrobial properties. Particulate Science and Technology. 2019: 1-8.

[89] N. Jayarambabu, A. Akshaykranth, T.V. Rao, et al. Green synthesis of $\mathrm{Cu}$ nanoparticles using Curcuma longa extract and their application in antimicrobial activity. Materials Letters. 2020, 259: 126813.

[90] M. Buttacavoli, N.N. Albanese, G. Di Cara, et al. Anticancer activity of biogenerated silver nanoparticles: an integrated proteomic investigation. Oncotarget. 2018, 9(11): 9685.

[91] N. Sharma, G. Arya, R.M. Kumari, et al. Evaluation of Anticancer activity of Silver Nanoparticles on the A549 Human Lung Carcinoma Cell Lines through Alamar Blue Assay. Bioprotocol. 2019, 9(1): e3131.

[92] S. Rajeshkumar, C. Malarkodi, M. Vanaja, et al. Anticancer and enhanced antimicrobial activity of biosynthesizd silver nanoparticles against clinical pathogens. Journal of Molecular Structure. 2016, 1116: 165-173.

[93] V. Castro-Aceituno, S. Ahn, S.Y. Simu, et al. Anticancer activity of silver nanoparticles from Panax ginseng fresh leaves in human cancer cells. Biomedicine \& Pharmacotherapy. 2016, 84: 158-165.

[94] T. Wu, X. Duan, C. Hu, et al. Synthesis and characterization of gold nanoparticles from Abies spectabilis extract and its anticancer activity on bladder cancer T24 cells. Artificial cells, nanomedicine, and biotechnology. 2019, 47(1): 512-523.

[95] S.V.P. Ramaswamy, S. Narendhran, R. Sivaraj. Potentiating effect of ecofriendly synthesis of copper oxide nanoparticles using brown alga: antimicrobial and anticancer activities. Bulletin of Materials Science. 2016, 39(2): 361-364.

[96] V. Gnanavel, V. Palanichamy, S.M. Roopan. Biosynthesis and characterization of copper oxide nanoparticles and its anticancer activity on human colon cancer cell lines (HCT-116). Journal of Photochemistry and Photobiology B: Biology. 2017, 171:133-138.

Copyright $(\subset$ Tayyab Shafiq, Mohammad Uzair, Muhammad Junaid Iqbal, Mohsin Zafar, Syed Jawad Hussain, and Syed Alasar Ali Shah. This is an open-access article distributed under the terms of the Creative Commons Attribution License, which permits unrestricted use, distribution, and reproduction in any medium, provided the original author and source are credited. 